\title{
The Mediterranean Sea Basin as a Single Ecosystem: Problems and Prospects for International Cooperation
}

\author{
Victor N. Egorov ${ }^{1} \bowtie$, Ludmila V. Malakhova1 ${ }^{1}$, Andrey Kh. Degterev ${ }^{2} \mathbb{D}$, Mikhail N. Yurlov ${ }^{3}$ \\ ${ }^{1}$ A.O. Kovalevsky Institute of Biology of the Southern Seas, Russian Academy of Sciences, \\ Moscow, Russian Federation \\ ${ }^{2}$ Sevastopol State University, Sevastopol, Russian Federation \\ ${ }^{3}$ Fond "Sevastopol", Sevastopol, Russian Federation \\ $\bowtie$ egorov.ibss@yandex.ru
}

\begin{abstract}
The article justifies that the Mediterranean Basin in the broad sense (Mediterranean, Black, Azov and Marmara Seas) is a single ecosystem. The state of this ecosystem is affected by the rivers of this water intake basin, among them - the Nile, Tiber, Po, Rhone, Ebro, Danube, Don and others. The interconnection of the individual elements of the ecosystem is ensured through active water exchange and a sufficiently branched system of currents that turn the inland seas of the Mediterranean basin into communicating vessels. The paper analyzes the main anthropogenic factors, as well as the influence of climate changes on the ecological condition of the Mediterranean ecosystem. Within the framework of anthropogenic impact, special attention is paid to the negative impact of urbanization, the oil industry (production, transportation and oil refining), industrial and agricultural waste, as well as runoff waters. The problem of plastic, as well as contamination with dichlorodiphenyltrichloroethane (DDT) is discussed in detail. Analysis of DDT accumulations in the bottom sediments of the Mediterranean basin makes it possible to study the synchronization of anthropogenic processes and their long-term nature. Aridization (intensification of droughts) in the Mediterranean is shown as an important problem for the regional ecology, not directly related to the anthropogenic factor. The article reveals the disastrous effects of increasing droughts and climate change on Mediterranean basin countries. International cooperation to regulate transboundary environmental problems in the region is associated with a number of problems. Among them is the delimitation of sea zones between countries, first of all - the territorial claims of Turkey in the Eastern Mediterranean. The problem of the shelf around the Serpents' Island in the Black Sea is also considered, as well as territorial disputes in the Western Mediterranean (France/Spain). The paper widely presents successful cases of cross-boundary cooperation: the 1976 RAMOGE Agreement, the 1975 Mediterranean Action Plan and the 1995 Barcelona Convention, as well as its seven protocols. The cases of PEGASO and 4GreenInn projects, as well as the BSEC environmental projects, are considered as successful examples of cross-border academic cooperation. Promising areas of cooperation are outlined and the conclusion is made about the importance of transboundary environmental risk management, despite the political differences between the Mediterranean countries and the EU sanctions restrictions on Russia after 2014.
\end{abstract}

Key words: Mediterranean Sea, ecosystem, ecology, anthropogenic factor, pesticides, transboundary pollution, aridization, international cooperation, RAMOGE, MAP, Barcelona convention, BSEC, BSTDB

Acknowledgements: A.O. Kovalevsky Institute of Biology of the Southern Seas team worked within the framework of the internal R\&D project "Molismological and biogeochemical foundations of homeostasis of marine ecosystems" (state assignment No. 121031500515-8). The authors also thank the anonymous reviewers for their valuable comments.

(C) Egorov V.N., Malakhova L.V., Degterev A.Kh., Yurlov M.N., 2021

This work is licensed under a Creative Commons Attribution 4.0 International License.

https://creativecommons.org/licenses/by/4.0/ 
For citation: Egorov, V. N., Malakhova, L. V., Degterev, A. Kh., \& Yurlov, M. N. (2021). The Mediterranean Sea basin as a single ecosystem: Problems and prospects for international cooperation. Vestnik RUDN. International Relations, 21(4), 625-641. https://doi.org/10.22363/2313-0660-2021-21-4-625-641

\title{
Бассейн Средиземного моря как единая экосистема: проблемы и перспективы международного сотрудничества
}

\author{
В.Н. Егоров ${ }^{1} \mathbb{D}$, Л.В. Малахова ${ }^{1} \mathbb{D}$, А.Х. Дегтерев ${ }^{2}$, М.Н. Юрлов ${ }^{3}$ \\ ${ }^{1}$ Институт биологии южных морей им. А.О. Ковалевского РАН, Москва, Российская Федерация \\ ${ }^{2}$ Севастопольский государственный университет, Севастополь, Российская Федерация \\ ${ }^{3}$ Фонд «Севастополь», Севастополь, Российская Федерация \\ \egorov.ibss@yandex.ru
}

\begin{abstract}
Аннотация. Показано, что Средиземноморский бассейн в широком смысле (Средиземное, Черное, Азовское и Мраморное моря) представляет собой единую экосистему. На состояние данной экосистемы влияют реки этого водозаборного бассейна, среди них - Нил, Тибр, По, Рона, Эбр, Дунай, Дон и др. Взаимосвязь отдельных элементов экосистемы обеспечивается посредством активного водообмена и достаточно разветвленной системы течений, которые превращают внутренние моря Средиземноморского бассейна в сообщающиеся сосуды. Представлен анализ основных антропогенных факторов, а также влияние изменения климата на экологическое состояние средиземноморской экосистемы. В рамках антропогенного воздействия особое внимание уделено негативному влиянию процессов урбанизации, нефтяной промышленности (добыча, транспортировка и нефтепереработка), промышленным и сельскохозяйственным отходам, а также стоковым водам. Подробно рассмотрена проблема пластика, а также загрязнения дихлордифенилтрихлорэтаном (ДДТ). Анализ накоплений ДДТ в донных отложениях Средиземноморского бассейна позволяет исследовать синхронизацию антропогенных процессов и их долгосрочный характер. Аридизация (усиление засух) в Средиземноморье показана как важная проблема для региональной экологии, не связанная непосредственно с антропогенным фактором. Раскрываются пагубные последствия усиления засух и изменения климата для стран Средиземноморского бассейна. Международное сотрудничество, призванное регулировать трансграничные проблемы окружающей среды в регионе, связано с целым рядом проблем. Среди них - разграничение морских зон между странами, в первую очередь - территориальные притязания Турции в Восточном Средиземноморье. Также исследуется проблема шельфа вокруг о. Змеиный в Черном море, а также территориальные споры в Западном Средиземноморье (Франция / Испания). Широко представлены успешные примеры международного сотрудничества на примере Соглашения RAMOGE 1976 г., Средиземноморского плана действий 1975 г. и Барселонской конвенции 1995 г., а также ее семи протоколов. На примере проектов PEGASO, 4GreenInn, а также экологических проектов Организации Черноморского экономического сотрудничества рассматриваются примеры трансграничного академического взаимодействия. В заключении обозначены перспективные направления сотрудничества и делается вывод о важности трансграничного управления экологическими рисками, даже несмотря на политические разногласия стран - участниц Средиземноморья, а также санкционные ограничения ЕС в отношении России после 2014 г.

Ключевые слова: Средиземное море, экосистема, экология, антропогенный фактор, пестициды, трансграничное загрязнение, аридизация, международное сотрудничество, RAMOGE, MAP, Барселонская конвенция, Организация черноморского экономического сотрудничества, Черноморский банк торговли и развития
\end{abstract}

Благодарности: Сотрудники ИнБЮМ выполняли работу в рамках темы НИР ФИЦ ИнБЮМ «Молисмологические и биогеохимические основы гомеостаза морских экосистем» (№ госзадания 121031500515-8). Авторы также благодарят анонимных рецензентов за ценные комментарии.

Для цитирования: Egorov V.N., Malakhova L.V., Degterev A.Kh., Yurlov M.N. The Mediterranean Sea Basin as a Single Ecosystem: Problems and Prospects for International Cooperation // Вестник Российского университета дружбы народов. Серия: Международные отношения. 2021. Т. 21. № 4. С. 625-641. DOI: 10.22363/23130660-2021-21-4-625-641

\section{Introduction}

The Mediterranean basin is a single ecosystem, the elements of which are interconnected. This concerns both the direct anthropogenic impact (pollution of coastal areas and sea waters with industrial and agricultural waste), and the influence of natural and climatic factors, including an increase in average 
temperature and a decrease in precipitation, leading to aridization of the region and a shortage of fresh water. A number of Mediterranean countries are taking some measures at the national and regional levels, but they are not enough to solve urgent environmental problems. Despite the existing contradictions and political differences, international cooperation between the countries of the region is an urgent necessity. There are a number of successful cross-border cooperation projects, the experience of which is also analyzed in this paper.

The methodology of this article is interdisciplinary, combining both natural science and social science approaches. The team of authors includes researchers of marine ecosystems (A.O. Kovalevsky Institute of Biology of the Southern Seas), a specialist in climate change (Sevastopol State University), as well as a leading expert on international political and international legal issues in the Mediterranean basin. Combining their efforts made it possible to reach a qualitatively new level of studying the problems of transboundary cooperation in the field of environmental protection.

\section{The Mediterranean Sea Basin as a Single Ecosystem}

The Mediterranean Sea has an area of 2,500,000 $\mathrm{km}^{2}$ and a maximum depth of $5,121 \mathrm{~m}$. Such large rivers as the Nile, Tiber, Po, Rhone, and Ebro flow into it, and the boundaries of the water intake basin run through the Pyrenees, the Alps, the mountains of the Balkan Peninsula, the Atlas Mountains, the Taurus, Zagros, Lebanon, and others. The linear dimensions of the sea are estimated at 3700$3750 \mathrm{~km}$ from west to east and $1200-1800 \mathrm{~km}$ from north to south.

The ecosystem of the Mediterranean Sea can be conventionally divided into two large parts the Western Mediterranean and the Eastern Mediterranean (Fig. 1), each of which, in turn, includes a number of inland seas.

In the Western subsystem, these are the Alboran Sea (between Spain and Morocco), the Balearic Sea (between Spain and the Balearic Islands), the Ligurian Sea (between Italy and Corsica) and the Tyrrhenian Sea (between the Apennine Peninsula, Sardinia and Sicily). In the Eastern subsystem, these are the Adriatic Sea (between Italy and the former republics of Yugoslavia), the Ionian Sea (between Greece and

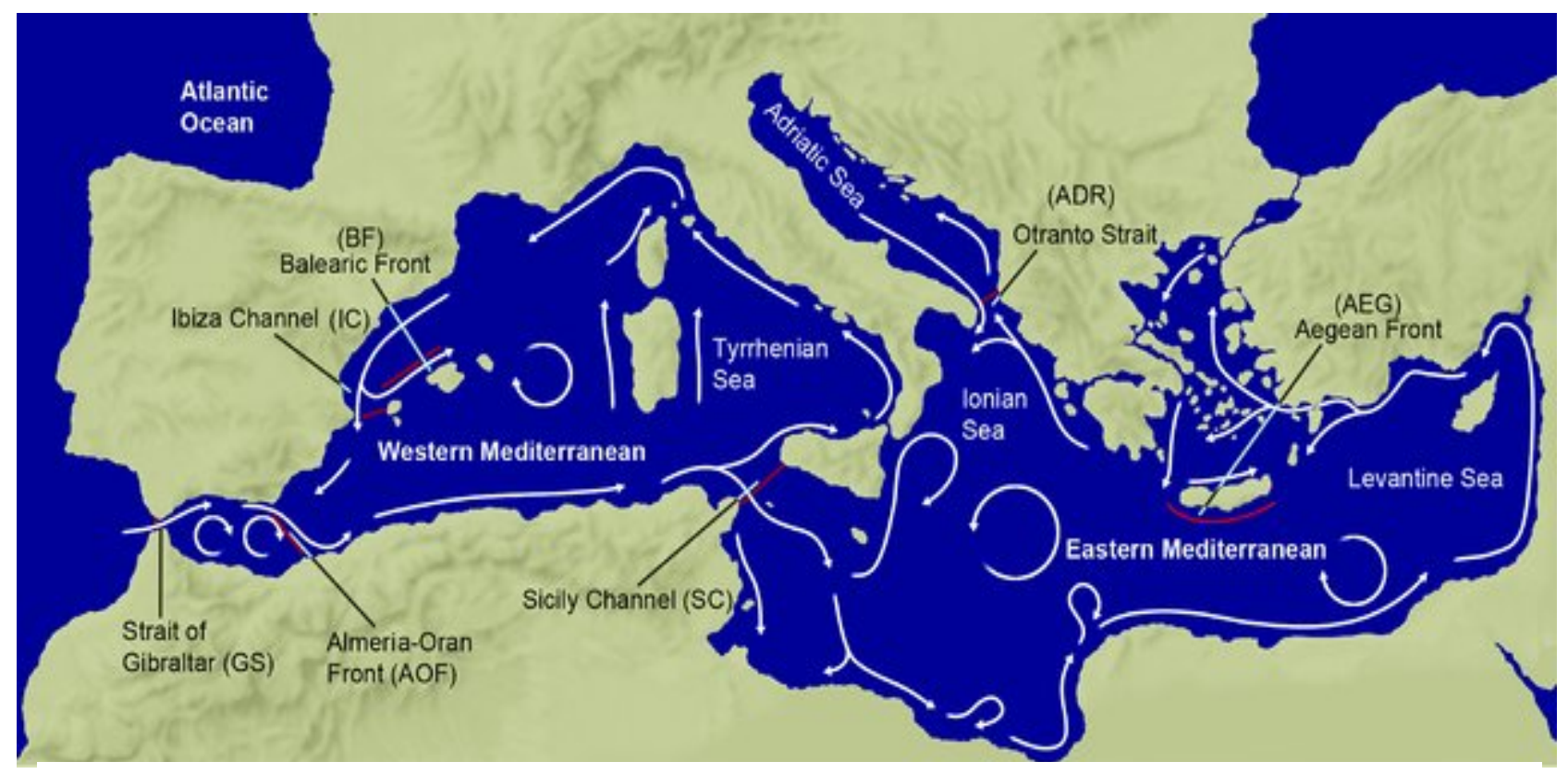

Fig. 1. Sub-Basins of Mediterranean Sea Source: (Pascual et al., 2017, p. 3).

Note: White lines indicate main currents, red lines - oceanographic fronts. 


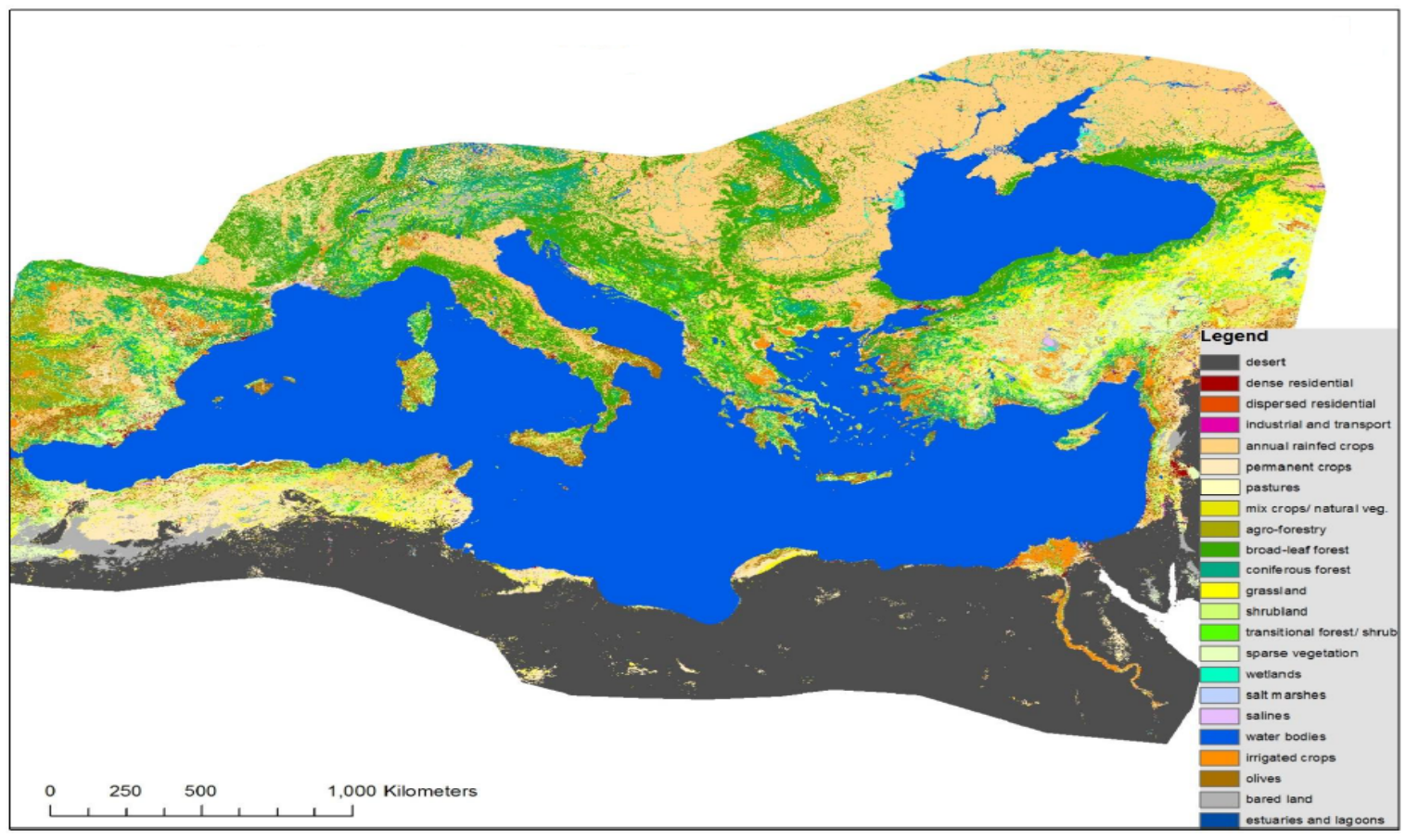

Fig. 2. Cover zones in Great Mediterranean

Source: PEGASO Final publishable summary report // PEGASO Project. 2014.

URL: http://www.vliz.be/projects/pegaso/images/stories/reports/PEGASO\%20Publishable\%20summary_ 140328_FBR.pdf (accessed: 15.11.2021).

Sicily), and the Aegean Sea (between Greece and Turkey). Within the Eastern subsystem, one can also distinguish the Libyan Sea (northeast of Libya), the Levantine Sea (eastern part of the Mediterranean), and divide the Aegean Sea into a number of inland seas (Cretan, Myrtoi, etc.).

In a number of studies, the Mediterranean Sea basin is considered in a broad context together with the Black Sea basin, which also belongs to the Atlantic drainage basin. In this case, the Black Sea, the Sea of Azov and the Sea of Marmara also belong to the ecosystem of the Mediterranean Sea in a broad sense. The interaction of the Black and Mediterranean Sea basins is gaining particular relevance in the context of Turkey's construction of the artificial shipping channel "Istanbul," which has been under way since June $2021 .{ }^{1}$

In geopolitics, the Red Sea basin is also sometimes referred to as the Greater

${ }^{1}$ A $\$ 15$ bn New Canal for Istanbul // The Economist. October 9, 2021. URL: https://www.economist.com/ europe/2021/10/09/a-15bn-new-canal-for-istanbul (accessed: 15.11.2021).
Mediterranean (Aghazada, 2021, p. 432), but this inland sea of the Indian Ocean and its coast belongs to a different drainage basin. On the other hand, the Nile River Basin, which covers a large part of Northeast Africa, is closely linked to the Mediterranean ecosystem.

Water exchange between the seas of the Mediterranean basin is provided by a fairly extensive system of currents (Fig. 1). Their speed in the open parts of the sea is $0.5-1.0 \mathrm{~km} \mathrm{~h}-1$, and in the straits it can increase to $2-4 \mathrm{~km} \mathrm{~h}-1$. Even with an average speed of currents of $1 \mathrm{~km}$ $\mathrm{h}-1$, the water exchange of surface waters of the sea can occur on less than a half-year time scale. It is obvious that the seas of the Mediterranean basin are communicating vessels and ecologically significant processes of migration of pollution in their waters take place on the same time scale. Therefore, a negative mutual influence of economic zones of different countries of the Mediterranean basin is possible. If the southern coast of the Mediterranean Sea is dominated by the desert cover due to the extremely arid climate, then on the northern coast there are also deciduous forests (Fig. 2). 


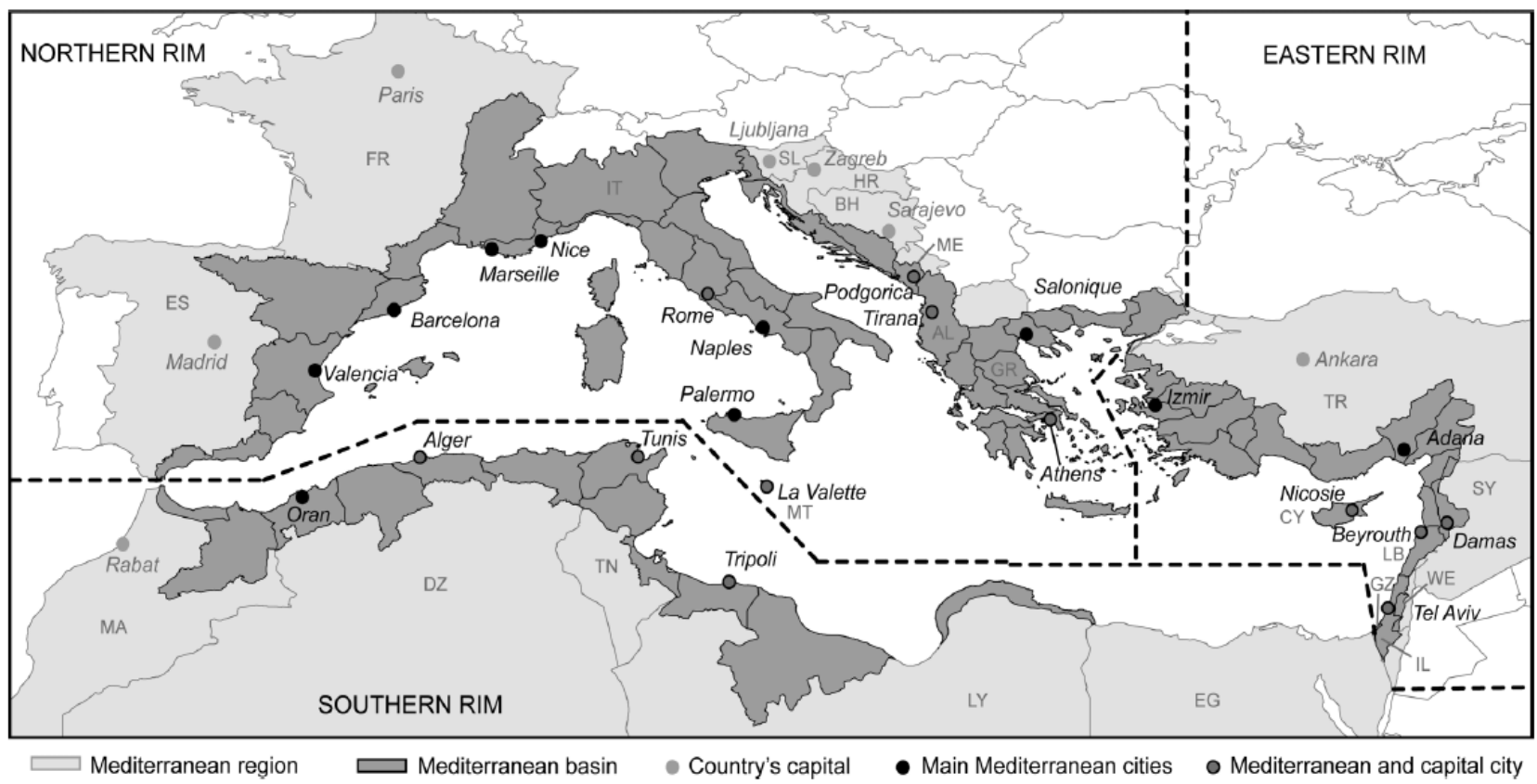

Fig. 3. Largest cities on the Mediterranean coast

Source: (Milano et al. 2013, p. 500).

Acronyms: ES: Spain, FR: France, IT: Italy, SL: Slovenia, HR: Croatia, BH: Bosnia and Herzegovina, ME: Montenegro, AL: Albania, GR: Greece, TR: Turkey, MT: Malta, CY: Cyprus, SY: Syria, LB: Lebanon, IL: Israel, EG: Egypt, WE: West Bank, GZ: Gaza Strip, LY: Libya, TN: Tunisia, DZ: Algeria, MA: Morocco.

The coastal areas together with the system of inland seas form a single ecosystem of the Mediterranean Sea.

\section{Transboundary Environmental Problems in the Mediterranean}

The Mediterranean ecosystem is characterized by a number of problems related to pollution of both coastal areas and seawater. Coastal areas, especially those near the mouths of rivers, are the most polluted. The causes of pollution are most often industrial waste, untreated municipal wastewater, agricultural pollution, as well as excessive anthropogenic load associated with active tourism and intensive, often chaotic development of the coastal zone.

Part of the Mediterranean Sea is polluted with oil, for example, off the coast of Libya, where oil is extracted on an industrial scale. The largest oil refineries in France are located on the Mediterranean coast near Marseille. One of the large-scale oil pollution occurred in February 2021 off the coast of Lebanon and Israel, which led to serious damage to the environment, as well as the temporary closure of all Israeli beaches. ${ }^{2}$

The impact of the anthropogenic factor is intensified by urbanization - a number of capitals and major cities are located on the Mediterranean coast, such as Barcelona, Marseille, Rome, Algiers, Tunis, Tripoli, Athens, Tel Aviv, Alexandria and others (Fig. 3).

Urban agglomerations are powerful sources of air emissions, including sulfur dioxide, as well as polluting seawater through runoff. The problem is particularly acute in the threemillionth Rome. On the Turkish coast, due to the large amount of waste water, there is a phenomenon called "red tides" — the spread of toxic microflora occurring in water rich in phosphorus and nitrogen. ${ }^{3}$

${ }^{2}$ Rinat Z., Zikri A. Oil Spill off Israel's Coast Is Its Worst Maritime Pollution in Decades, and Cleanup "Could Take Years"// Haaretz. February 19, 2021. URL: https://www.haaretz.com/israel-news/.premium-oil-spilloff-israel-s-coast-is-its-worst-maritime-pollution-indecades-1.9553528 (accessed: 15.11.2021).

${ }^{3}$ Red Tide Poses Risk for Sea Ecosystem // Hürriyet Daily News. April 26, 2013. URL: 


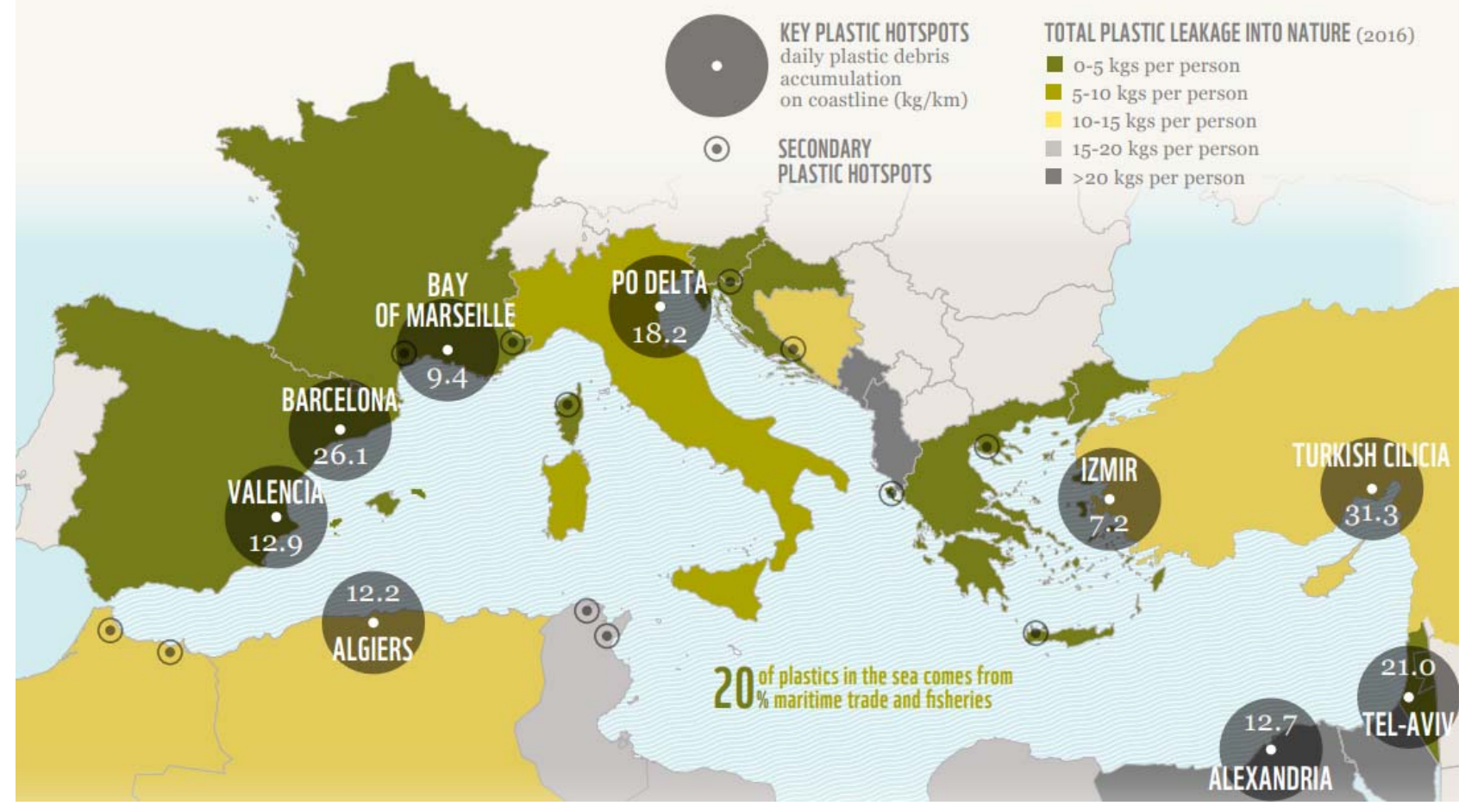

Fig. 4. Coastal Hotspots of Plastic Pollution in the Mediterranean

Source: Stop the flood of plastic. How Mediterranean countries can save their sea. World Wide Fund for Nature. 2019. URL: https://awsassets.panda.org/downloads/a4_plastics_reg_low.pdf (accessed: 15.11.2021).

A separate problem is plastic, 0.57 million tons of which annually enter the Mediterranean Sea (out of 24 million produced in the region). The strong tourist flow increases pollution by one-third. $20 \%$ of plastic enters the water from merchant ships and fishing boats, as the Mediterranean is a zone of active shipping. In general, plastic has an extremely negative impact on marine flora and fauna. ${ }^{4}$ The largest emissions of plastic into the water area occur on the southwest coast of Turkey, in the agglomerations of Barcelona, Tel Aviv, in the Po delta (Italy), Valencia, Algiers, etc. (Fig. 4).

The analysis of spreading of the most ecologically dangerous chlorinated hydrocarbons, DDT, in bottom sediments is a vivid example illustrating all harmfulness of transboundary sea water pollution in the long term, as well as

https://www.hurriyetdailynews.com/red-tide-poses-riskfor-sea-ecosystem-45663 (accessed: 15.11.2021).

${ }^{4}$ Stop the Flood of Plastic. How Mediterranean Countries Can Save Their Sea // World Wide Fund for Nature. 2019. URL: https://awsassets.panda.org/ downloads/a4_plastics_reg_low.pdf (accessed: 15.11.2021). synchronization of anthropogenic processes occurring within a single ecosystem of the Mediterranean basin. The introduction of dichlorodiphenyltrichloroethane, or DDT, to combat insect pests that destroy agricultural crops and also carry deadly diseases, revolutionized agricultural production and medicine. The use of DDT contributed to the elimination of malaria and typhus in the United States and Europe. DDT was widely used against vectors of these diseases from World War II through the 1960s. It is estimated that global production and use of DDT exceeded 4,500,000 tons in 1948-1993 (Li \& Macdonald, 2005).

Gradually, it became clear that the widespread distribution of DDT, its relatively high fugacity and properties such as persistence and lipophilicity, led to the fact that traces of DDT appeared in all areas of the world, even the most inaccessible for humans. By the end of the 1960s, the toxic properties of DDT had been identified not only for insects, but also for animals of higher links of the trophic chain and for humans (Beard, 2006). DDT was banned in 
most Western European countries. Some states in the Eastern Mediterranean (Cyprus, Egypt, Israel, Libya, and Turkey) have not used chlorinated pesticides since 1985 (Li \& Macdonald, 2005). In 2001, the International Stockholm Convention was adopted to reduce the production and eliminate emissions of already produced persistent organic pollutants, the original list of which included DDT. ${ }^{5}$

Despite the potential danger of DDT to the environment and human health, its use is permitted in circumstances where the benefits of its use outweigh the associated risk. Thus, DDT was widely used in the African continent to combat malaria at the beginning of the $21 \mathrm{st}$ century, since there are still no effective alternatives (Ranson et al., 2011). Moreover, at the WHO level, the need for DDT use on a large scale in the face of climate change and possible outbreaks of insect-borne diseases is now being re-justified (Mandavilli, 2006). In China, technical DDT is still used as an additive in nonfouling paints for fishing boats (Xu et al., 2013). In these circumstances, the problem of DDT pollution of the environment currently refers to the phenomena, the elimination or minimization of negative consequences from which require the development of international agreements both at the global and regional levels.

The sources of DDT entering marine ecosystems are river and storm terrigenous runoff, releases of untreated municipal wastewater, aerosol atmospheric fallout, rain and snowfall, dumping, discharges from ships, as well as exchange of water masses with neighboring seas. Due to its high hydrophobicity and adhesive properties, DDT in water binds to suspended particles and is transported with them over long distances or partially removed from the water into bottom sediments, where it can accumulate in large quantities over time. During remobilization of bottom sediments, the DDT buried in them can re-enter the aquatic ecosystem and its food chain, therefore, data on their content in sediments are important for

\footnotetext{
${ }^{5}$ Overview // The Stockholm Convention. 2001. URL: http://chm.pops.int/TheConvention/Overview/tabid/3351/ Default.aspx (accessed: 15.11.2021).
}

predicting the levels of pollution of water bodies during planned hydraulic works and possible emergency events. In addition, data on the state of bottom sediments are the most important source of retrospective information on the history of ecosystems of water bodies, since the composition of the soil strata makes it possible to assess the processes taking place at the time of their formation and development, including the chronology of accumulation of pollutants.

An overview of DDT content in bottom sediments from different regions of the Mediterranean Sea is presented in Table 1. Hereinafter, DDT means the sum of concentrations of the original pesticide DDT and its metabolic products, DDE (dichlorodiphenyldichloroethylene) and DDD (dichlorodiphenyldichloroethane), the first of which is even more toxic than DDT.

Table 1

Concentration of (Dichlorodiphenyltrichloroethane) DDT in Bottom Sediments of the Mediterranean Sea

\begin{tabular}{|c|c|c|c|}
\hline Region & $\begin{array}{c}\text { Years } \\
\text { of study }\end{array}$ & $\begin{array}{l}\text { Concentration } \\
\text { of DDT, ng / g }\end{array}$ & Source \\
\hline $\begin{array}{l}\text { Alexandria } \\
\text { Harbour, Egypt }\end{array}$ & 1998 & $0.3-885$ & $\begin{array}{l}\text { (Barakat et al., } \\
2002 \text { ) }\end{array}$ \\
\hline $\begin{array}{l}\text { Cyprus } \\
\text { Northern Shelf }\end{array}$ & 2016 & $1.27-108$ & $\begin{array}{l}\text { (Kucuksezgin } \\
\text { et al., 2016) }\end{array}$ \\
\hline $\begin{array}{l}\text { Rhone River } \\
\text { Delta }\end{array}$ & $\begin{array}{l}1987- \\
1991\end{array}$ & $62-675$ & $\begin{array}{l}\text { (Tolosa et al., } \\
1995)\end{array}$ \\
\hline $\begin{array}{l}\text { Ebro River } \\
\text { Delta }\end{array}$ & $\begin{array}{l}1987- \\
1991\end{array}$ & $3.5-11.5$ & $\begin{array}{l}\text { (Tolosa et al., } \\
1995)\end{array}$ \\
\hline $\begin{array}{l}\text { Coastal } \\
\text { Barcelona }\end{array}$ & $\begin{array}{l}1987- \\
1991\end{array}$ & 76.2 & $\begin{array}{l}\text { (Tolosa et al., } \\
1995)\end{array}$ \\
\hline Gulf of Lyon & $\begin{array}{l}1987- \\
1991\end{array}$ & $3.5-11.5$ & $\begin{array}{l}\text { (Tolosa et al., } \\
1995)\end{array}$ \\
\hline Catalan Sea & $\begin{array}{l}1987- \\
1991\end{array}$ & $3.1-5.4$ & $\begin{array}{l}\text { (Tolosa et al., } \\
1995)\end{array}$ \\
\hline $\begin{array}{l}\text { Coastal } \\
\text { Ligurian Sea }\end{array}$ & 1999 & $2.5-25$ & $\begin{array}{l}\text { (Bertolotto et } \\
\text { al., 2004) }\end{array}$ \\
\hline $\begin{array}{l}\text { Open Adriatic } \\
\text { Sea }\end{array}$ & 1990 & $0.03-11.3$ & $\begin{array}{l}\text { (De Lazzari et } \\
\text { al., 2004) }\end{array}$ \\
\hline Adriatic Sea & 1997 & $0.2-35.0$ & (Picer, 2000) \\
\hline Ionian Sea & 1999 & $0-6.2$ & $\begin{array}{l}\text { (Lelekis et al., } \\
2001 \text { ) }\end{array}$ \\
\hline $\begin{array}{l}\text { Coastal Areas } \\
\text { of Egypt }\end{array}$ & $\begin{array}{l}1989- \\
1991\end{array}$ & $32-223$ & $\begin{array}{l}\text { (Abd-Allah \& } \\
\text { Abbas, 1992) }\end{array}$ \\
\hline $\begin{array}{l}\text { Coastal Areas } \\
\text { of Egypt }\end{array}$ & 2007 & $0.11-50.73$ & $\begin{array}{l}\text { (El Nemr \& El- } \\
\text { Sadaawy, 2016) }\end{array}$ \\
\hline $\begin{array}{l}\text { Saronic Gulf, } \\
\text { Keratsini Bay }\end{array}$ & 1998 & $9100-75600$ & $\begin{array}{l}\text { (Galanopoulou } \\
\text { et al., 2005) }\end{array}$ \\
\hline
\end{tabular}

Source: compiled by the authors. 


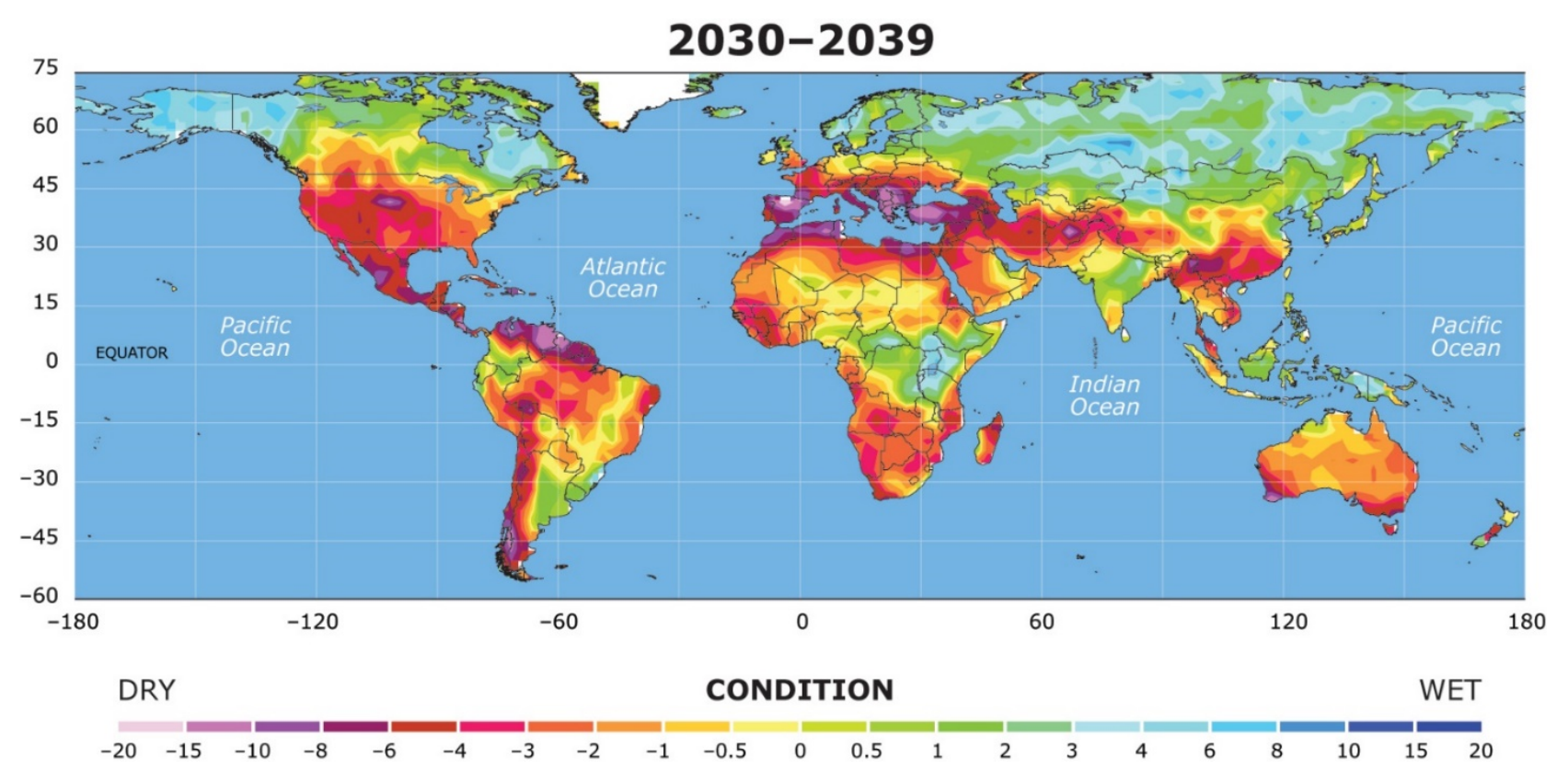

Fig. 5. Mean annual PDSI for 2030-2039

Source: (Dai, 2011, p. 59).

The data presented in the table show that the differences in DDT levels reflected different degrees of agricultural industrialization, population density, and the impact of industrial and urban waste on pollution in the coastal and marine areas of the Mediterranean basin. Therefore, data on the distribution of DDT in bottom sediments can be recommended as a basis for the development of international agreements on the regulation of permissible discharges into the environment in various economic zones of the Mediterranean basin in the future.

\section{Aridization as a Regional Problem}

In addition to the direct anthropogenic factor, the Mediterranean ecosystem is also affected by other transboundary problems, some of which are related to natural and climatic changes. One of the main consequences of the current global climate change for the Mediterranean countries, along with the rise in temperature, is the intensification of droughts. This affects both the increase in dryland area and the duration of droughts.

If now the arid areas here on average account for less than $30 \%$, after a global warming of $3^{\circ} \mathrm{C}$ their area will be $50 \%$.
According to forecasts made by the Intergovernmental Panel on Climate Change (IPCC) based on climate change calculations using climate models, it is the Mediterranean countries that will be most affected by droughts in the coming years. ${ }^{6}$ This can be clearly seen in the Palmer Drought Severity Index (PDSI) projection map in 20 years, shown in Figure 5.

It should be noted that we are talking about the coming decades, not about climate change in the distant future. Moreover, the process of increasing drought in the Mediterranean countries is already underway. And this is not just another increase in drought with its subsequent rapid easing. A study of the width of annual tree rings, carried out by NASA specialists, showed that the drought in the Mediterranean countries in 1998-2012 was $50 \%$ more severe than all droughts in the last 500 years. In this case, cuts of trees from Spain, Italy, France, from the countries of North Africa and the Mediterranean coast of the Middle East were used (Cook et al., 2016).

The most difficult situation is in the countries, where along with a high value of the

\footnotetext{
${ }^{6}$ Kokorin A.O. Climate Change: Review of the Fifth Assessment Report of the IPCC. Moscow: World Wildlife Fund (WWF), 2014. P. 52.
} 
drought index there is a lack of water resources. Thirteen countries/territories of the Mediterranean basin (i.e. more than one third) are among the top-33 countries with the greatest water shortage in 2040, including (in descending order of problem severity) San Marino, Palestine, Israel, Jordan, Libya, Macedonia, Morocco, Syria, Turkey, Greece, Algeria, Spain and Tunisia. ${ }^{7}$

Drought was one of the causes of the Arab Spring in Tunisia, Libya, Egypt and several other countries in the region (Johnstone \& Mazo, 2011). In particular, the severe drought in Syria from 2006-2011 led to water shortages and poor harvests for several years, which, in turn, caused food shortages, unemployment, and increased social tensions. This subsequently led to civil war and migration from Syria (de Châtel, 2014).

The worst drought in 150 years was in Spain in 2014, when the country was close to a complete depletion of drinking water resources. ${ }^{8}$ In addition to water shortages, the dangers of droughts in the Mediterranean include forest fires, significant overconsumption of electricity for air conditioning, and loss of life. For example, during the abnormally hot summer of 2003 in Europe, 70 thousand people died from heat waves, with 15,000 in France in August alone (Fink et al., 2004). In recent years, droughts have also led to numerous fires in southern Europe, and the forests in France, Spain, and Portugal were on fire.

According to the forecasts of climatologists, the duration of heat-waves in southern Europe will increase, and by the end of the century they will be two months longer. According to the estimates of the Max Planck Institute in the Middle East countries already by 2050 the temperature in the summer even at night will not drop below $30^{\circ} \mathrm{C}$, and at noon it will reach $46^{\circ} \mathrm{C}$. In this regard, by 2050 the number of

\footnotetext{
${ }^{7}$ Maddocks A., Young R. S., Reig P. Ranking the World's Most Water-Stressed Countries in 2040 // World Resources Institute. August 26, 2015. URL: https://www.wri.org/insights/ranking-worlds-most-waterstressed-countries-2040 (accessed: 15.11.2021).

${ }^{8}$ Exceptional Drought in South-Eastern Spain // EU Science Hub. August 12, 2014. URL: https://ec.europa.eu/ $\mathrm{jrc/en/science-update/exceptional-drought-south-eastern-}$ spain (accessed: 15.11.2021).
}

climate refugees will reach 250 million people. Agriculture is particularly affected by droughts in the Mediterranean. During the three-year drought from 2017-2020, it killed 50 to $70 \%$ of the harvest of olives and grapes, which led to an increase in the price of olive oil in January 2021 in Italy by $44 \%$ compared to the previous year. The corresponding damage in Italy alone is estimated at 2 billion euros. And Italy and Spain are the main producers of olives. Vineyards in southern Europe are also severely damaged by droughts. In fact, agricultural lands in southern Europe are turning into a zone of risky farming (Rodrigo-Comino et al., 2021).

Increased droughts in the region also leads to changes in river flows and, consequently, in the regime of filling of reservoirs. In the Mediterranean river basins, spring floods are becoming weaker due to shorter winters and higher temperatures. On the other hand, the role of Mediterranean cyclones in increasing summer precipitation increases due to rising water temperatures in the Mediterranean Sea. In Europe, river runoff decreases from north to south and from west to east, so that the most difficult situation in this regard is in the Eastern Mediterranean. Construction of new and reconstruction of existing reservoirs is one of the ways to combat water shortages due to uneven precipitation. The use of bottled water is also on the rise in the region. ${ }^{9}$

Droughts are usually associated with high temperatures, that is, heat waves. However, although related, these are different phenomena. The severity of a soil drought is usually determined not by air or soil temperature, but by the duration of the drought. Thus, severe droughts include situations when more than four consecutive dry decades are observed without interruption. And if by the increase in the maximum air temperature the Mediterranean countries practically do not stand out among other countries of mainland Europe (Fig. 6a), then by the increase in the duration of droughts they stand out significantly.

\footnotetext{
${ }^{9}$ The Impact of Draught on Drinking Water // EarEau Briefing Note. July, 2020. URL: https://www.eureau.org/ resources/briefing-notes/5111-briefing-note-on-the-impactof-drought-on-drinking-water/file (accessed: 15.11.2021).
} 


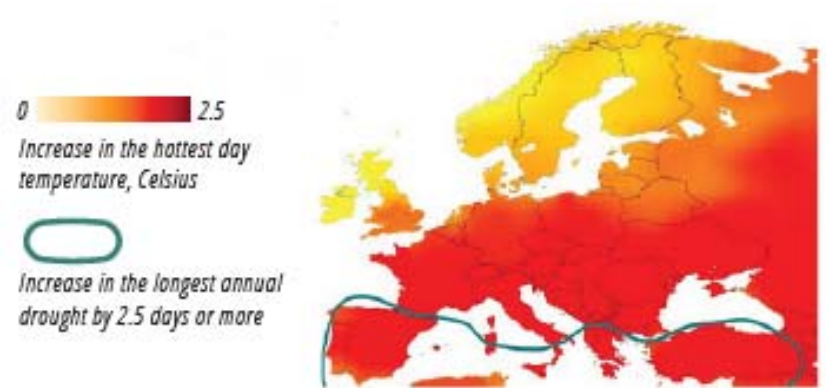

Fig. 6a. Changes in maximum temperature and drought by 2040 in Europe

Source: Global Trends 2040: A More Contested World // National Intelligence Council. 2021.

URL: https:/www.dni.gov/files/ODNI/documents/ assessments/GlobalTrends_2040.pdf (accessed: 15.11.2021).

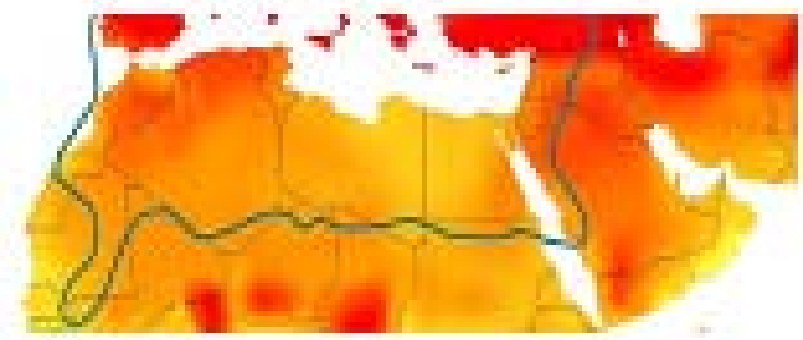

Fig. 6b. Changes in maximum temperature and drought by 2040 in Middle East

Source: Global Trends 2040: A More Contested World // National Intelligence Council. 2021.

URL: https:/www.dni.gov/files/ODNI/documents/ assessments/GlobalTrends_2040.pdf (accessed: 15.11.2021).

For comparison, Fig. $6 \mathrm{~b}$ shows a similar map for the Middle East, which shows that the increase in maximum temperatures on the hottest days in North Africa is significantly lower, while the Mediterranean countries also fall into the zone of increasing drought. It is the superimposing of heat waves on drought that becomes characteristic of the region. In this case, on the one hand, evapotranspiration increases, which intensifies drought, and, on the other hand, the lack of moisture does not allow lowering the high temperature through evaporation and transpiration.

\section{Problematic Aspects of International Cooperation}

The Mediterranean ecosystem is territorially divided between 21 countries. These are Spain, France, Italy, Monaco, Malta, Slovenia, Croatia, Bosnia and Herzegovina, Montenegro, Albania, Greece, Cyprus, Turkey, Syria, Lebanon, Israel, Egypt, Libya, Tunisia, Algeria and Morocco
(Fig. 3). A number of other countries are located in the Black Sea basin: in addition to the already mentioned Turkey, these are the Russian Federation, Ukraine, Bulgaria, Romania, Georgia, Abkhazia, and Moldova near the mouth of the Danube. Each party has its own foreign policy interests, the result of which leads to the formation of a regional balance of power (Irkhin \& Moskalenko, 2020).

There is intense competition between countries in the use of natural and climatic resources (fishing, tourism). Problems in one country's tourism industry, including environmental disasters, are seen as unique opportunities to lure tourists from another country. There are no plans for the joint development and use of fragile transboundary ecosystems (Berzi \& Ariza, 2018).

A separate acute problem is the territorial disputes between the states. The problem of Turkish territorial claims in the Eastern Mediterranean has already been discussed in detail on the pages of this magazine (Gudev, 2021). A more detailed analysis of maritime disputes is presented in the classic monograph by W. Prescott and C. Schofield (Schofield \& Prescott, 2005), as well as on a specialized portal. ${ }^{10}$ A thorough analysis of all major maritime disputes in the Mediterranean Sea is not the subject of this article. It is rather an illustration of the negative impact of this factor on regional cross-border cooperation.

The Turkish claims in the Eastern Mediterranean are perhaps the most extensive territorial disputes in the Mediterranean basin (Fig. 7).

The problem of territorial claims in the Eastern Mediterranean is exacerbated by the discovery in the 2000s of large offshore natural gas deposits, as well as plans to build the East Mediterranean Gas Pipeline (East Med).

In the Eastern Mediterranean, there are also unresolved maritime disputes between Turkey and the Republic of Cyprus over maritime zones, between Palestine and Israel and Egypt; between Israel and Lebanon; between Syria and Turkey (the borders are not delimited).

${ }^{10}$ Boundaries // Sovereign Limits. URL: https://sovereignlimits.com/boundaries (accessed: 15.11.2021). 


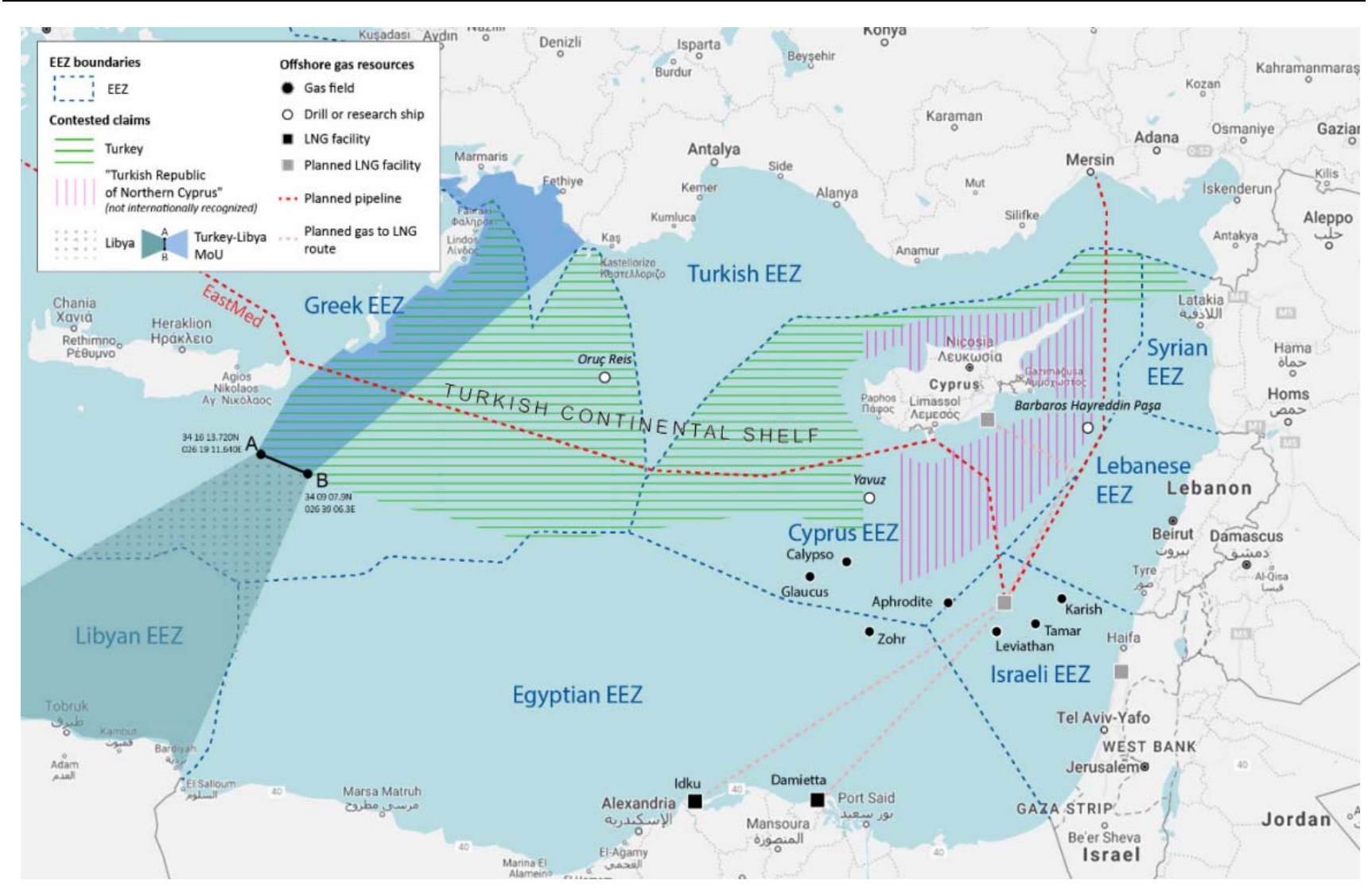

Fig. 7. Delimitation in the Eastern Mediterranean

Source: Stanicek B. Turkey: Remodelling the Eastern Mediterranean. Conflicting Exploration of Natural Gas Reserves // European Parliamentary Research Service. 2020.

URL: https://www.europarl.europa.eu/RegData/etudes/BRIE/2020/652048/EPRS_BRI(2020)652048_EN.pdf (accessed: 15.11.2021).

There is also a difficult situation in the Black Sea - in the waters around the Republic of Crimea, whose accession to the Russian Federation has led to the de facto need to delimit maritime spaces with both Ukraine and Romania, to confirm the maritime border with Turkey. Moreover, there is the water area of the Republic of Abkhazia, which is not recognized by Georgia.

In 2004-2009, there was a trial between Ukraine and Romania at the UN International Court of Justice related to the delimitation of sea borders and the division of the continental shelf around the Serpents' Island. Romania got 9.7 thousand out of 12 thousand square kilometers of the general area of the shelf. ${ }^{11}$

${ }^{11}$ Cour Internationale de Justice. Recueil des arrêts, avis consultatifs et ordonnances. Délimitation maritime en Mer Noire (Roumanie c. Ukraine). Arrêt du 3 février 2009. URL: https://web.archive.org/web/20150416202430/ http://www.icj-cij.org/docket/files/132/14987.pdf (accessed: 15.11.2021).
This case is one of the successful examples of settling this kind of disputes, in which the Romanian received predominant benefits.

In the Western Mediterranean, a dispute can be distinguished between Spain and Morocco over separate coastal territories and islands, between Spain and Great Britain over Gibraltar (exacerbated in the context of Brexit), between Albania and Greece, as well as between Spain and France (Fig. 8). Let us dwell on the latter in a little more detail, since it just illustrates the impact on the development of cross-border cooperation in the environmental sphere.

Since the 1970s, France and Spain have different views on the maritime borders between them in the Gulf of Lyon. This complicates concerted action to form protected areas, one of which, the Gulf of Lyon Natural Marine Park, is partially located in the disputed marine zone and has been undergoing institutionalization since 2008 (Berzi \& Ariza, 2018, pp. 480-482). 


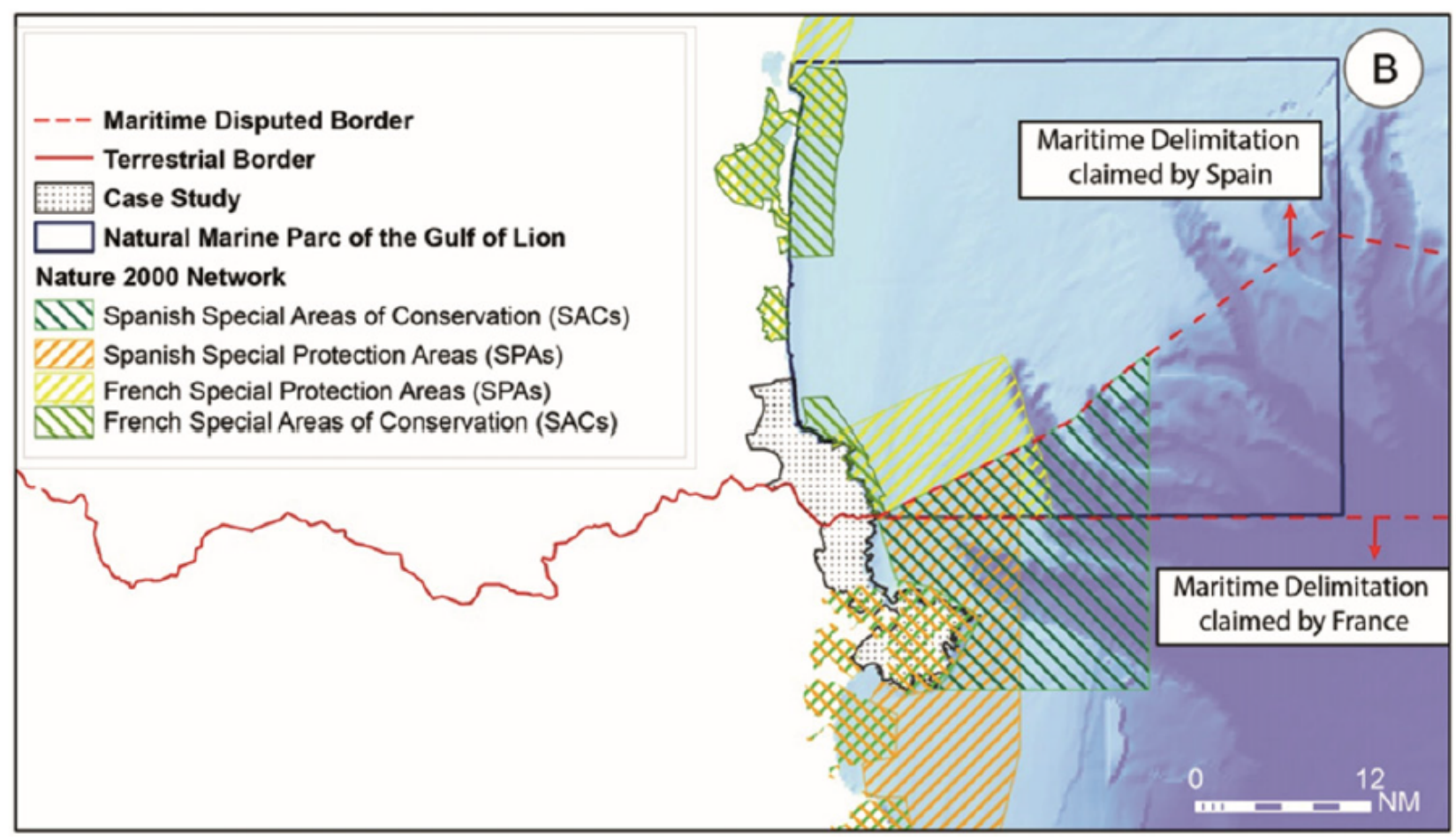

Fig. 8. Delimitation Disputes between France and Spain Source: (Berzi \& Ariza, 2018, p. 481).

Political cataclysms also have a strong negative impact on cross-border cooperation. In particular, the European Union, whose members are almost all countries located on the northern shore of the Mediterranean Sea (except for the former republics of Yugoslavia) after the Crimean and Ukrainian events of 2014 curtailed a number of joint programs, including in the scientific sphere, with Russian organizations, especially those located in the territory of the Republic of Crimea. In previous years, this cooperation was quite successful, as will be discussed below.

\section{Successful Examples of Transboundary Cooperation}

One of the first successful examples of transboundary cooperation in the Mediterranean Sea is the RAMOGE Agreement signed in May 1976 between France, Monaco and Italy on joint environmental activities in the coastal experimental zone. The agreement was named after the first letters of three cities: Saint Raphael (RA), Monaco (MO) and Genoa (GE), but later the zone was extended to Marseille (France) and
La Spezia (Italy). The agreement provides for interaction in the scientific, technical, legal and administrative spheres. If at the first stage (before 1990) mainly joint researches were carried out, since 1990 a number of joint practical actions in the field of ecology was implemented. The working bodies are a committee, a technical committee and working groups. $^{12}$

The 53rd session on the implementation of the RAMOGE agreement was held in Monaco in January 2021. It discussed the creation of the brand "RAMOGE" for sustainable yachting and looked at the prospects for collaboration with other transboundary protected areas, including the Park of Lyons (France - Spain) and the Algeria - Morocco - Tunisia trilateral agreement. Participants also discussed the creation of textbooks for high school students on the need to conserve the sea depths using data from joint RAMOGE studies. The participants also discussed the issue of creating textbooks for

${ }^{12}$ The RAMOGE Agreement // International Atomic Energy Agency. 1998. URL: https://inis.iaea.org/search/ search.aspx?orig_q=RN:30039024 (accessed: 15.11.2021). 
high school students on the need to preserve the sea depths using data obtained in the course of joint research through RAMOGE. ${ }^{13}$

A number of important regional agreements have been signed in collaboration with the United Nations Environment Program (UNEP) since 1975, when 16 Mediterranean countries and the European Community approved the Mediterranean Action Plan (MAP-1) as a multilateral environmental agreement, updated in 1995 (MAP-2). Under the joint auspices of UNEP/MAP, a framework convention to protect the Mediterranean Sea from pollution was adopted in Barcelona in $1976 .{ }^{14}$ After the Earth Summit in Rio de Janeiro in 1992, it became necessary to revise some provisions of the convention. In 1995, an updated version of the Convention for the Protection of the Marine Environment and the Coastal Region of the Mediterranean Sea (Barcelona Convention) was adopted and signed by 21 Mediterranean countries ${ }^{15}$ and the European Community.

The convention implies joint actions to assess and control pollution of coastal resources, to eliminate such pollution and to protect natural and cultural heritage. To specify the provisions of the convention, seven additional protocols have been developed and adopted, including the Discharge Protocol (from ships and aircraft), the Prevention and Emergency Protocol (pollution from ships and emergencies), the Protocol on Land-based Sources and Activities, the Protocol on Specially Protected Areas and Biological Diversity, the Marine Protocol (pollution from exploration and exploitation), the Protocol on Hazardous Waste and the Protocol on Integrated Coastal Zone Management (ICZM). Ministerial conferences on the implementation of the main

${ }^{13}$ Brodie J. RAMOGE Agreement Commission Goes Above and Beyond in Mediterranean Preservation // Monaco Daily News. January 29, 2021. URL: https://news.mc/ 2021/01/29/ramoge-agreement-commission-goes-aboveand-beyond-in-mediterranean-preservation/ (accessed: 15.11.2021).

${ }^{14}$ Mediterranean Action Plan (MAP) // UNEP. URL: https://www.unep.org/unepmap/ (accessed: 15.11.2021).

${ }^{15}$ Albania, Algeria, Bosnia and Herzegovina, Croatia, Cyprus, Egypt, France, Greece, Israel, Italy, Lebanon, Libya, Malta, Monaco, Montenegro, Morocco, Slovenia, Spain, Syria, Tunisia, Turkey. provisions of the MAP are held once every two years; the permanent secretariat is located in Athens (Greece). The Mediterranean Trust Fund was formed, with the main funding for the implementation of the MAP activities coming from the EU (including the EU's 8th Framework Program for the development of research and technology Horizon 2020 (2014-2020), as well as European Territorial Cooperation Programs), ${ }^{16}$ UN agencies and the Global Environment Facility (GEF). ${ }^{17}$

One of the successful collaborative projects under the ICZM Protocol was the People for Ecosystem-Based Governance in Assessing Sustainable Ocean and Coastal (PEGASO) project. ${ }^{18}$ It was implemented in 2010-2014 within the framework of the 7th EU Framework Program led by the Autonomous University of Barcelona (UAB) to develop joint approaches to the management of the coastal and marine zones of the Mediterranean and Black Sea basins. The project included both scientific collaboration and joint decision-making. 25 participants took part in the program, including universities and research centers from Spain, France, Great Britain, Italy, Switzerland, Morocco, Lebanon, Greece, Romania, Egypt and organizations from Belgium, Algeria, and Turkey. The participants include the Permanent Secretariat of the Commission for the Protection of the Black Sea against Pollution (Istanbul), as well as the Marine Hydrophysical Institute (Sevastopol) (PEGASSO 2014).

In the Black Sea basin, the initiative "Black Sea Transboundary Cooperation" (headquartered in Romania) was implemented within the framework of the European Neighborhood policy. A number of projects were financed in two stages (2007-2013, 2014 -2020) in all countries of the

\footnotetext{
${ }^{16}$ European Territorial Cooperation // European Parliament. URL: https://www.europarl.europa.eu/factsheets/ en/sheet/98/european-territorial-cooperation (accessed: 15.11.2021).

17 The Barcelona Convention // European Commission. URL: https://ec.europa.eu/environment/marine/internationalcooperation/regional-sea-conventions/barcelona-convention/ index_en.htm (accessed: 15.11.2021).

${ }^{18}$ PEGASO Project // Vlaams Institut Voor De Zee. URL: http://www.vliz.be/projects/pegaso/index.html (accessed: 15.11.2021).
} 
Black Sea basin, except Russia and Abkhazia. ${ }^{19}$ For example, in 2013-2016 the project "Innovations in Sustainable Management and Protection of Natural Areas" (4GreenInn) was implemented, within the framework of which the "Black Sea Ecopedia" was compiled. One of the project participants was the Fond "Sevastopol", which also connected the Marine Hydrophysical Institute (Sevastopol) and A.O. Kovalevsky Institute of Biology of the Southern Seas. The main operator of the project was the Municipality of Bourgas; among the participants was also the Regional Development Agency of the Southeastern Development Region of Romania (SERDA). ${ }^{20}$ After 2014, the participation of the Crimean organizations in the project was suspended. At the sixth meeting of the joint program committee of the initiative in September, 2021 with participation of 9 countries (Armenia, Bulgaria, Georgia, Greece, Moldova, Romania, Russia, Turkey and Ukraine) the main parameters of the cooperation program for 2021-2027 were discussed. ${ }^{21}$

Transboundary environmental projects are also being implemented by the Organization of the Black Sea Economic Cooperation (BSEC), whose members are both Black Sea and Mediterranean countries. Five environmental projects have been financed at the expense of the BSEC Project Development Fund. The BSEC Working Group on Environmental Protection developed the BSEC Climate Change Adaptation Strategy for the Black Sea, which was adopted by the Council of Ministers of Foreign Affairs of the organization on December $15,2017 .^{22}$

\footnotetext{
${ }^{19}$ Black Sea Cross Border Cooperation. URL: http://blacksea-cbc.net/ (accessed: 15.11.2021).

${ }^{20}$ Innovations in Sustainable Management and Protection of Natural Areas. Programme 2007-2013 Black Sea Basin ENPI CBC // European Union. URL: https://keep.eu/projects/15831/Innovations-in-sustainable-EN/ (accessed: 15.11.2021).

${ }^{21}$ The Sixth Meeting of the Joint Programming Committee for the Interreg NEXT Black Sea Basin Programme 2021-2027 // Black Sea Cross-Border Cooperation. September 30, 2021. URL: https://blackseacbc.net/news/archive-news/the-sixth-meeting-of-the-jointprogramming-committee-for-the-interreg-next-black-seabasin-programme-2021-2027/ (accessed: 15.11.2021).

${ }^{22}$ Environmental Protection // BSEC. URL: http://www.bsec-organization.org/areas-of-cooperation/ environmental-protection/information (accessed: 15.11.2021).
}

\section{Prospective Areas of Cooperation}

In connection with the observed and projected changes in the climate and environmental conditions, a number of promising areas of cooperation between Russia and the Mediterranean countries can be emphasized. One of them is to study the experience of cultivation of local crops in different countries of the region. Thus, back in 1926-1927, N.I. Vavilov organized a large expedition to the Mediterranean countries to collect samples of plants cultivated there. One of the goals was the subsequent use of collected samples for their cultivation in the south of Russia and the selection of new zoned varieties. Obviously, now the exchange of experience in growing various agricultural crops in the zones of extreme agriculture (in Russia, these include Krasnodar and Stavropol Territories, Crimea) is no less relevant. In recent years there has also been a noticeable increase in the export of crop products from Russia. The fact is that for Russia, the current climate change is generally favorable for the volume of agricultural production, while the drought in the Mediterranean countries has a greater impact on the cultivation of a number of crops.

Since the time of N.I. Vavilov's expedition, the importance of building a collection of the region's flora and fauna has not diminished either. But now we are already talking about the preservation of species diversity. Global drought is considered as one of the reasons for the possible extinction of a number of plant and animal species in nature. In this regard, projects like a lunar ark are already being developed to complement the existing plant seed vaults in Russia, Norway, and other countries.

Cooperation in extinguishing forest fires is no less urgent. Russia has extensive experience in assisting a number of Mediterranean countries with firefighting aviation. For example, in the summer of 2021, such assistance was provided to Greece and Turkey with the use of Russian aircrafts and helicopters on lease. ${ }^{23}$

${ }^{23}$ Turkey Wildfires: Satellite Images Show Devastation Caused by Deadly Fires, as 'Sabotage' Can't Be Ruled out // Sky News. July 31, 2021. URL: https://news.sky.com/ 
There are great prospects for international scientific cooperation in the joint creation of specialized databases. In particular, in 2020, Russian climatologists, together with their foreign colleagues created a database on tornadoes in Russia and 14 neighboring countries, which cover the period from the 10th century to $2018 .^{24}$ The exchange of knowledge and practical information (knowledge sharing) will make it possible to move on to the formation of joint mechanisms of early prevention of ecological risks. The agenda also includes environmental regulations for biodiversity conservation, regulations for the extraction of organic resources, preservation of spawning grounds and safe migration conditions for marine organisms, as well as development of environmental impact assessments for offshore hydrocarbon field development technologies.

It is important to understand that environmental issues have no borders and are not subject to sanctions. The high risks of exploiting fragile ecosystems, which include the Mediterranean and Black Sea basins, create an urgent need for transboundary cooperation on environmental protection.

In this context, the example of the antisanctions policy of Great Britain, which after leaving the EU, since January 2021 allows its companies to pay for pilotage services for the passage through the Kerch Strait and for the use of Crimean ports through the Crimean Seaports State Unitary Enterprise of the Republic of Crimea, is quite indicative. ${ }^{25}$ Life and safety of

story/turkey-wildfires-satellite-images-show-devastationcaused-by-deadly-fires-12368521 (accessed: 15.11.2021).

24 "The future of meteorology is in clear forecasts" // Russian Academy of Sciences [«Будущее метеорологии за четкими прогнозами» // PAH]. 21.07.2021. (In Russian). URL: http://www.ras.ru/news/shownews.aspx?id=fdd08ef 4-f008-40e9-9cfb-62ba3e3b7c69 (accessed: 15.11.2021).

${ }^{25}$ Great Britain Made Relief in the Sanctions Regime against Crimea // RBC [Великобритания сделала послабление в санкционном режиме против Крыма // РБК]. 06.01.2021. (In Russian). URL: https://www.rbc.ru/ politics/06/01/2021/5ff5ca339a7947199b57377d (accessed: 15.11.2021). navigation make foreign authorities forget about the sanctions, even if only on a point-by-point basis.

On the agenda is the resumption of transboundary cooperation between the Russian Federation and researchers from other Black Sea and Mediterranean countries on environmental issues in a depoliticized format. An important role in this regard could be played by cooperation within the BSEC, as well as through the Black Sea Trade and Development Bank (BSTDB). In this regard, the Russian Foreign Ministry stresses that 'Russia's interest in the BSTDB is explained by the Bank's ability to play a useful role in restoring Russia's cooperation with the CIS and Eastern European countries, as well as in ensuring economic cooperation with Turkey and Greece."26

\section{Conclusion}

The study of the ecological state of the marine environment of the Mediterranean basin as a single ecosystem as a whole has determined the need to consolidate research in the development of the legal and environmental framework for transboundary solutions to the environmental problems of the region. The interdisciplinary synthesis presented in the study has shown that it is promising to unite specialists from specialized scientific institutions and political departments for these purposes. The most successful examples of such cooperation were analyzed, as well as the main international political problems standing in the way of successful transboundary cooperation on environmental protection in the Mediterranean basin with the participation of all stakeholders were identified.

${ }^{26}$ Black Sea Trade and Development Bank // Russian Ministry of Foreign Affairs [Черноморский банк торговли и развития // МИД России]. 08.11.2016. (In Russian). URL: https://www.mid.ru/cernomorskijbank-torgovli-i-razvitia-cbtr-/-/asset_publisher/KrRBY5 EMiHC1/content/id/2514775 (accessed: 15.11.2021).

Received / Поступила в редакцию: 20.09.2021 Accepted / Принята к публикации: 26.10.2021 


\section{References / Библиографический список}

Abd-Allah, A. M., \& Abbas, M. M. (1992). Residue level of organochlorine pollutants in the Alexandria Region, Egypt. Toxicological and Environmental Chemistry, 41(3-4), 239-247. https://doi.org/10.1080/ 02772249409357979

Aghazada, M. M. (2021). Greater Mediterranean regional security complex: Myth or reality? Vestnik RUDN. International Relations, 21(3), 429 - 440. (In Russian). https://doi.org/10.22363/2313-0660-2021-21-3-429-440

Barakat, A. O., Moonkoo, K., Yoarong, Q., \& Wade, T. L. (2002). Organochlorine pesticides and PCB residues in sediments of Alexandria Harbour, Egypt. Marine Pollution Bulletin, 44(12), 1426-1434. https://doi.org/10.1016/s0025-326x(02)00313-2

Beard, J. (2006). DDT and human health. Science of the Total Environment, 355(1-3), 78-89. https://doi.org/10.1016/j.scitotenv.2005.02.022

Bertolotto, R. M, Magherini, A., Frignani, M., Bellucci, L. G., Alvarado-Aguilar, D., Cuneo, C., \& Albanese, S. (2004). Polychlorinated biphenyls and pesticides in surficial coastal sediments of the Ligurian Sea. Organohalogen Compounds, (66), 1379-1385.

Berzi, M., \& Ariza, E. (2018). A local transboundary approach to the governance of Mediterranean coastal borderlands. Coastal Management, 46(5), 471-487. https://doi.org/10.1080/08920753.2018.1498713

Cook, B. I., Anchukaitis, K. J., Touchan, R., Meko, D. M., \& Cook, E. R. (2016). Spatiotemporal drought variability in the Mediterranean over the last 900 years. Journal of Geophysical Research: Atmospheres, 121(5), 20602074. https://doi.org/10.1002/2015JD023929

Dai, A. (2011). Drought under global warming: A review. Wiley Interdisciplinary Reviews: Climate Change, 2(1), 45-65. https://doi.org/10.1002/wcc. 81

De Châtel, F. (2014). The role of drought and climate change in the Syrian uprising: Untangling the triggers of the revolution. Middle Eastern Studies, 50(4), 521-535. https://doi.org/10.1080/00263206.2013.850076

De Lazzari, A., Rampazzo, G., \& Pavoni, B. (2004). Geochemistry of sediments in the Northern and Central Adriatic Sea. Estuarine, Coastal and Shelf Science, 59(3), 429-440. https://doi.org/10.1016/j.ecss. 2003.10.003

El Nemr, A., \& El-Sadaawy, M. M. (2016). Polychlorinated biphenyl and organochlorine pesticide residues in surface sediments from the Mediterranean Sea (Egypt). International Journal of Sediment Research, 31(1), 44-52. https://doi.org/10.1016/j.ijsrc.2013.03.001

Fink, A. H., Brücher, T., Krüger, A., Leckebusch, G. C., Pinto, J. G., \& Ulbrich, U. (2004). The 2003 European summer heatwaves and drought-synoptic diagnosis and impacts. Weather, 59(8), 209-216. https://doi.org/10.1256/wea.73.04

Galanopoulou, S., Vgenopoulos, A., \& Conispoliatis, N. (2005). DDTs and other chlorinated organic pesticides and polychlorinated biphenyls pollution in the surface sediments of Keratsini harbour, Saronikos gulf, Greece. Marine Pollution Bulletin, 50(5), 520 - 525. https://doi.org/10.1016/j.marpolbul.2004.11.043

Gudev, P. A. (2021). Foundations of Turkish claims in the Eastern Mediterranean. Vestnik RUDN. International Relations, 21(3), 472 - 486. (In Russian). https://doi.org/10.22363/2313-0660-2021-21-3-472-486

Irkhin, A., \& Moskalenko, O. (2020). Russia's foreign policy in the Great Mediterranean: Prospects and constraints. Geopolitics Quarterly, 15(4), 110-121.

Johnstone, S., \& Mazo, J. (2011). Global warming and the Arab Spring. Survival, 53(2), 11-17. https://doi.org/10.1080/00396338.2011.571006

Kucuksezgin, F., Pazi, I., Gonul, L. T., \& Duman, M. (2016). Organochlorine compounds in surface sediments from the northern coast of Cyprus, Eastern Mediterranean: Levels, possible sources and potential risk. Marine Pollution Bulletin, 109(1), 591-596. https://doi.org/10.1016/j.marpolbul.2016.05.034

Lelekis, J., Petalas, S., Hatzianestis, I., \& Sklivagou, E. (2001). Determination of anthropogenic organic compounds in the sediments of a deltaic-coastal area. The case of Igoumenitsa Gulf and Kalamas river. 7th International Conference on Environmental Science and Technology, 3-6 September, Syros, Greece: proceedings, 2, $1211-1217$.

Li, Y. F., \& Macdonald, R. W. (2005). Sources and pathways of selected organochlorine pesticides to the Arctic and the effect of pathway divergence on HCH trends in biota: A review. The Science of the Total Environment, 342(1-3), 87-106. https://doi.org/10.1016/j.scitotenv.2004.12.027

Mandavilli, A. (2006). Health agency backs use of DDT against malaria. Nature, 443, 250-251. https://doi.org/10.1038/443250b 
Milano, M., Ruelland, D., Fernandez, S., Dezetter, A., Fabre, J. et al. (2013). Current state of Mediterranean water resources and future trends under climatic and anthropogenic changes. Hydrological Sciences Journal, 58(3), 498-518. https://doi.org/10.1080/02626667.2013.774458

Pascual, M., Rives, B., Schunter, C., \& Macpherson, E. (2017). Impact of life history traits on gene flow: A multispecies systematic review across oceanographic barriers in the Mediterranean Sea. PLoS ONE, 12(05), 1-20. https://doi.org/10.1371/journal.pone.0176419

Picer, M. (2000). DDTs and PCBs in the Adriatic Sea. Croatica Chemica Acta, 73(1), 123-186.

Ranson, H., N'Guessan, R., Lines, J., Moiroux, N., Nkuni, Z., \& Corbel, V. (2011). Pyrethroid resistance in African anopheline mosquitoes: What are the implications for malaria control? Trends Parasitol, 27(2), 91-98. https://doi.org/10.1016/j.pt.2010.08.004

Rodrigo-Comino, J., Salvia, R., Quaranta, G., Cudlín, P., Salvati, L., \& Gimenez-Morera, A. (2021). Climate aridity and the geographical shift of olive trees in a Mediterranean Northern region. Climate, 9(64), 1-17. https://doi.org/10.3390/cli9040064

Schofield, C., \& Prescott, V. (2005). The Maritime political boundaries of the world. Leiden: Martinus Nijhoff Publishers.

Tolosa, I., Bayona, J., \& Albaiges, J. (1995). Spatial and temporal distribution, fluxes and budgets of organochlorinated compounds in Northwest Mediterranean sediments. Environmental Science and Technology, 29(10), 2519-2527. https://doi.org/10.1021/es00010a010

Xu, Y. Y., Wang, Y. H., Li, J., Liu, X., Zhang, R. J. et al. (2013). Distributions, possible sources and biological risk of DDTs, HCHs and chlordanes in sediments of Beibu Gulf and its tributary rivers, China. Marine Pollution Bulletin, 76(1-2), 52 - 60. https://doi.org/10.1016/j.marpolbul.2013.09.032

\begin{abstract}
About the authors: Egorov Victor Nikolaevich - Russian Academy of Sciences member, PhD, Dr. of Sc. (Biology), Professor, Scientific Director, A.O. Kovalevsky Institute of Biology of the Southern Seas, Russian Academy of Sciences; ORCID: 0000-0002-4233-3212; e-mail: egorov.ibss@yandex.ru

Malakhova Ludmila Vasilievna - PhD in Biology, Leading Researcher, Department of Radiation and Chemical Biology, A.O. Kovalevsky Institute of Biology of the Southern Seas, Russian Academy of Sciences; ORCID: 0000-0001-8810-7264; e-mail: malakh2003@list.ru

Degterev Andrey Kharitonovich - PhD, Dr. of Sc. (Physics and Mathematics), Professor, Department of Radioecology and Environmental Safety, Institute of Nuclear Energy and Industry, Sevastopol State University; ORCID: 0000-0003-0170-6390; e-mail: degsebal@mail.ru

Yurlov Mikhail Nikolaevich - PhD in Law, Executive Director, Fond "Sevastopol"; e-mail: ymission@mail.ru
\end{abstract}

\footnotetext{
Сведения об авторах: Егоров Виктор Николаевич - академик РАН, доктор биологических наук, профессор, научный руководитель ФИЦ «Институт биологии южных морей им. А.О. Ковалевского РАН»; ORCID: 0000-0002-4233-3212; e-mail: egorov.ibss@yandex.ru

Малахова Людмила Васильевна - кандидат биологических наук, ведущий научный сотрудник отдела радиационной и химической биологии ФИЦ «Институт биологии южных морей им. А.О. Ковалевского PAH»; ORCID: 0000-0001-8810-7264; e-mail: malakh2003@list.ru

Дегтерев Андрей Харитонович - доктор физико-математических наук, профессор, профессор кафедры радиоэкологии и экологической безопасности Института ядерной энергии и промышленности Севастопольского государственного университета; ORCID: 0000-0003-0170-6390; e-mail: degsebal@mail.ru Юрлов Михаил Николаевич - кандидат юридических наук, исполнительный директор Фонда «Севастополь»; e-mail: ymission@mail.ru
} 